\title{
Laborious playgrounds: citizen science games as new modes of work/play in the digital
}

\author{
Anne Dippel \\ Sonia Fizek
}

This is the author's version of a book chapter published in The Playful Citizen: Civic Engagement in a Mediatized Culture (2018) edited by R. Glas, et al.

ISBN 9789462984523 


\title{
Laborious Playgrounds: Citizen science games as new modes of work/play in the digital age.
}

Anne Dippel

Sonia Fizek

\section{New modes of work/play in the digital age}

\begin{abstract}
If anything could be said to characterize new modes of work/play, it would be precisely this sort of interplay. (O’Donnell 2014, 12)
\end{abstract}

The computer screen gradually fills up with ever more complex geometrical patterns. Thousands of players go online to combine and rearrange colorful building blocks. With every level, the shapes become more refined, the patters harder to build, and the achievements more difficult to obtain. The leaderboards with the highest scores are published online and available to the entire playing community. Also the in-game mission outcomes are shared via social media platforms.

The game outlined above would not differ substantially from other abstract online digital puzzles, such as Bejeweled (2001) or Candy Crush (2012), if it were not for one crucial detail - its collaborative drive for an external goal. EteRNA (2010) constitutes a big data-driven digital laboratory (Virtual Lab. Play a Game. Change the World.), where more than 38.000 citizen player-scientists assemble shapes representing ribonucleic acids (RNAs), tiny molecules that are the basis of every living cell. The best virtual RNA designs are selected and synthesized in the biochemistry laboratory at Stanford.

Like numerous other citizen science games (also known as serious games, human-based computation games, or games with a purpose, GWAP), EteRNA is an example of a much broader playful/laborious phenomenon, which has been emerging in recent years. The term itself is opening up three significant fields for the understanding of citizen science games as playful collaborations for a common goal lying outside of the game itself.

The "citizen" emphasizes the importance of the collaborative social element, lying at the etymological heart of the Proto-Germanic word "game" ( $g a$ - together, mann - man). In digital games such as EteRNA masses of citizens are crucial, for their collaborative endeavors not only influence the gameworld, but more importantly reach outside of it, and contribute to the production of knowledge. The "scientific" dimension provides an external goal for the citizen players. It is placed in the realm of seriousness, associated with work. The "game" on the other hand, with its freedom of action within internal rules, achievement-based mechanics, and playful aesthetics, belongs to the realm of play performed for leisure. Those three aspects become the points of departure in the analysis of this recent phenomenon as a work and play interference, where both qualities permeate each other.

Citizen science games could be discussed in terms of gamification (Deterding et al. 2011) of science (introducing playful elements into an originally non-game context), but this explanation seems to be leading only in one direction - play entering the non-game domain and changing it into a playful entity. However, in this encounter, not only the gamified or ludified activity changes, but also play itself is undergoing transformation. Citizen science games may be perceived as laborious playgrounds, placed between the two poles of ludus and labora, oscillating between qualities associated previously either with pastime or with productive or useful time. 
In the following article, drawing upon interdisciplinary academic approaches of game studies, media theory and socio-cultural anthropology, we are going to discuss this relationship, and analyze citizen science games as the new modes of work/play, where both qualities overlap.

\section{Collaborative gaming with purpose}

We're calling on gamers to help connect the dots by creating a physical, visual 3D map of the brain.

(Eyewire n.d.)

Large collaborative online environments such as citizen science games are the most recent incarnation of ideas that were put into practice already a few decades ago. The first attempts to use collaborative power of humankind in combination with games were proposed at the beginning of the 1960s by Buckminister Fuller, who introduced the World Game, an educational simulation for solving the problems of overpopulation and uneven distribution of global resources. As the author himself claimed, he had played it without the assistance of computers since 1927. The World Game that Fuller envisioned was to be a place where individuals or teams of people compete, or cooperate, in order to:

[m]ake the world work, for $100 \%$ of humanity, in the shortest possible time, through spontaneous cooperation, without ecological offense or the disadvantage of anyone. (Buckminister Fuller Institute n.d.)

Fuller conceptualized a playful systemic tool that could engage masses of participants in a strategic game based on the statistical data concerning the world, its minerals, manufactured goods and services, humans and their needs (Buckminister Fuller Institute n.d.). However, what he did not have at his disposal, were the essential components of today's collaborative digital games with purpose: big data, the calculating machine able to process the deluge of information, and a network that would connect thousands of minds. The turning point came in 1989 with the invention of the World Wide Web (at CERN by Tim Berners-Lee). Its rise contributed to the development of a new gameplay phenomenon - a massively multiplayer online game (MMOG). ${ }^{1}$ It is only in the 1990's and the beginnings of 2000's that a game world could be populated by millions of players simultaneously. One of the most recognizable MMORPG titles, World of Warcraft (2004), in its peak had 12 million active players (Statista).

What if those millions of participants, instead of performing fictitious online battles, were united in order to solve existing and potentially problematic scenarios, following Fuller's vision? Collectively, we spend three billion hours a week gaming (McGonigal 2010). Why not turning this affluence of pastime into productive time, and collaborative gameplay into socially positive ends - asked game designer Jane McGonigal (2010, 2011)? To achieve this McGonigal used Alternate Reality Games (ARGs), combining the physical world with the online world, where role-play turns into real-play, as she emphasizes. In 2007 World without Oil - "a massively collaborative imagining of the first 32 weeks of a global oil crisis" - launched online. The players contributed with their own stories and possible scenarios via e-mail, fora, uploaded video material, or comics. The game attracted 1.800 players. Evoke (2010), the next collaborative ARG, brought together more than 20.000 people all over the world with a common goal to find solutions to the most urgent social problems, such as food shortage, water crisis, or women empowerment, amongst others.

The productive, anticipatory and systemic real-play has been perfected in the most recent collaborative ludic phenomenon - citizen science games. In contrast to previous ARGs, citizen science games unite all the players online within a consistent game platform with specific rules and tasks to perform. Within those big data collaborative play spaces players solve puzzles, categorize, identify and tag data, participate in challenges, and by doing so contribute to the advancement of scientific research. The free digital labor (Scholz 2013) of thousands of amateur science-players helps researchers deal with

\footnotetext{
${ }^{1}$ The first multiplayer real time virtual worlds, such as Multi User Dungeons (MUDs) rose at the end of 1970's and 1980's. They could be, however, played online exclusively as experiments in the ARPANET network or within internal university networks.
} 
numerous questions, from biology, neuroscience, astronomy, high-energy physics, to linguistics and history of art, amongst others. The players predict protein patterns (EteRNA), map neural retina pathways (Eye Wire), classify the morphologies of galaxies (Galaxy Challenge), program algorithms identifying the Higgs boson (Higgs Boson Machine Learning Challenge), tag social language (Metropolitalia) or art works (ARTigo).

One of the first citizen science games was FoldIT (2008 "Solve Puzzles for Science"). It was developed as an online challenge of synthesizing molecules. The input from the online playful laboratory turned out to be so successful that its initial prototype transformed into a worldwide ludic experiment renamed EteRNA (2010 "Make Molecules, Advance Science"), developed as a scientific project at Stanford and Carnegie Mellon Universities. Its gameplay is based on the complex pattern recognition process. The player's task is to assemble shapes representing ribonucleic acids (RNAs). Since humans are currently much more efficient in deciphering and predicting the structures of proteins than the existing computer algorithms, the initiators of the project decided to use the form of an online puzzle to attract potential participants. Their actions are collected in a big data assemblage with the aim to improve the development of algorithms for pattern recognition.

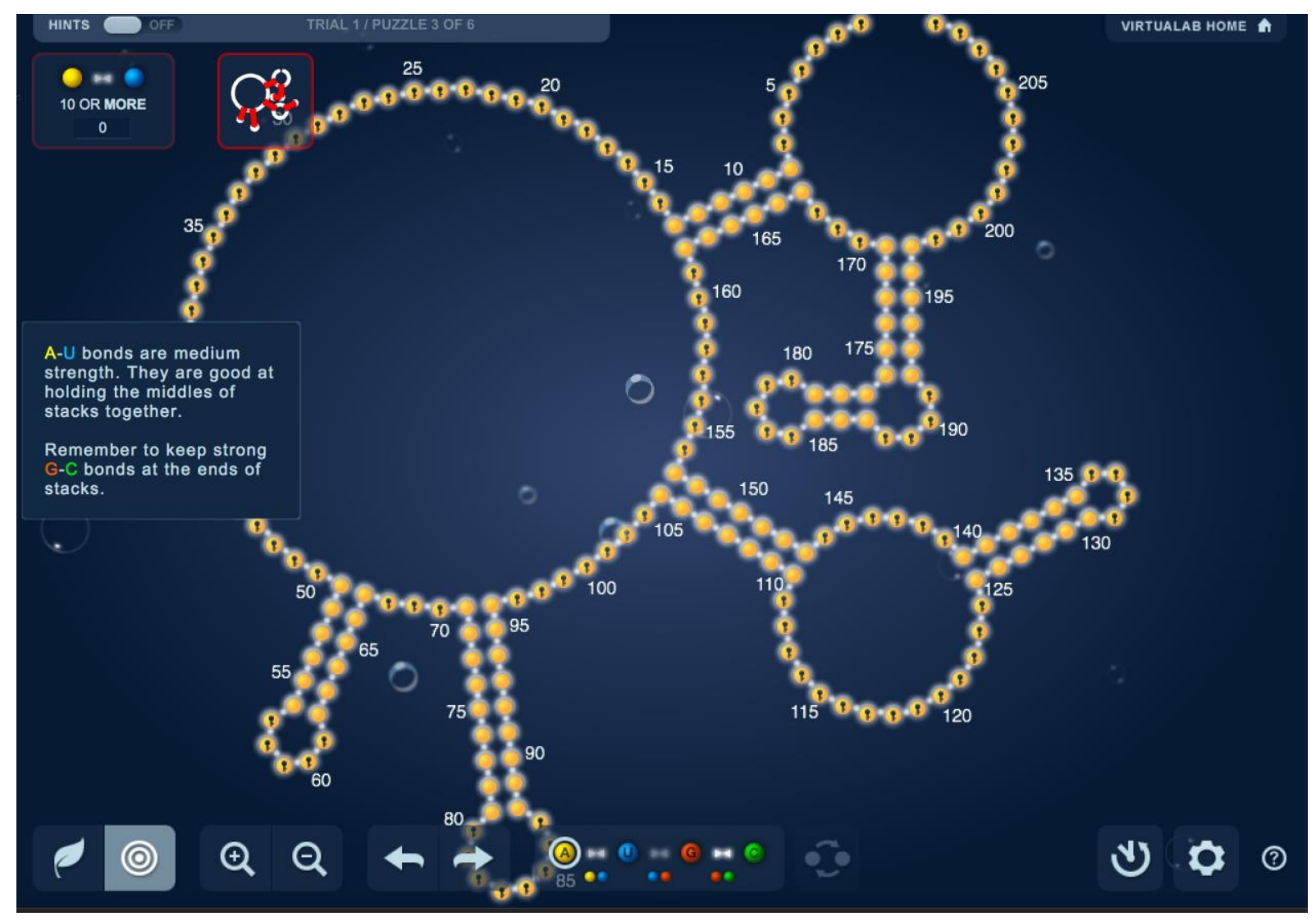

Fig. 1 A screen from the gameplay in EteRNA (2010)

Big data collaborative games and challenges have become such an effective scientific tool in the past few years that they led to the development of entire online platforms for collaborative volunteer research such as Kaggle ${ }^{2}$ or Zooniverse ${ }^{3}$, amongst others, where academic institutions and research centers may create their games, outsourcing the challenges to the citizens around the world.

Those lofty and idealistic attempts to change the world by turning gaming into something productive embody what Alexander Galloway (2013) refers to as contemporary romantico-cybernetic

\footnotetext{
${ }^{2}$ Available at: http://www.kaggle.com.

${ }^{3}$ Available at: http://www.zooniverse.org.
} 
understanding of play. On the one hand, play is perceived as a spontaneous, careless and almost childlike activity. On the other, in many instances, it has become almost synonymous with complex iterative systems. Commercialization and systematization of play, gamification, or productive collective gaming operate in accordance with the systemic and structural quality of play. At the same time, they draw from the Huizingian spirit, associating play with something pure, almost poetic, and above all else meant to entice pleasure. And this romantico-cybernetic fusion invites the humans into the world of something they intuitively associate with pleasure and frivolity, all the while performing productive tasks with an external purpose.

\section{Work and play interference}

Play turns to seriousness and seriousness to play. (Huizinga 1938/1992, 8)

The process of blurring the work-play and seriousness-playfulness lines was first brought to attention in the last chapter of Homo Ludens (1938/1992), where Johan Huizinga discusses the loss of the purity of a frivolous playful experience and emphasizes the confusion of where play ends and non-play begins. To support his claim, he uses the example of professional sports, which systematizes pure play and corrupts it through the principles of paid work. He then moves on to the world of commercial rivalry and emphasizes the agon element in business, noticing that "... some of the great business concerns deliberately instill the play-spirit into their workers so as to step up production" (Huizinga 1938/1992, 200). By doing so, according to Huizinga, they turn business into play, and as a result play becomes business. The two allegedly mutually exclusive aspects of human practice, work and play, interfere and transform the everyday life. Their boundaries collapse and as a result playfulness leaks into labor, and the latter unfolds moments of drudgery within play.

Huizingian distinction between play and work, and the portrayal of the latter as a productive and paid activity relates to the Marxist understanding of work ethic. For Karl Marx work is defined as a useful and productive activity that may be translated into the value of commodities produced. It is also part of a natural human behavior, "... a productive expenditure of human brain, muscle, nerve, hand, etc." (Marx 1887/2015 n.d.). In the Grundrisse he also points out the Abrahamic definition of work as toil which seems to have been placed on the human shoulders in the moment of the ancestral sin: "In the sweat of thy face shalt thou eat bread, till thou return unto the ground; for out of it wast thou taken: for dust thou art, and unto dust shalt thou return" (Genesis 3:19; KJV). While the foundational text of Abrahamic monotheism represents work in terms of a curse enforced upon humans by God, Marx departs from it and defines work as a chance for the "individual's self-realization", an a priori act of utmost freedom, which encompasses happiness, even if throughout history mostly corrupted, selfalienated forms of work or "external forms of labour" have become visible $(1858 / 1973,611)$. In this, he rejects the understanding of Adam Smith, who argued that work "...obtains its measure from the outside through the aim to be attained and the obstacles to be overcome in attaining it" (Elster 1999, 59).

The differentiation between work and play appears already in Aristotle's Nicomachean Ethics (1971). Both above qualities, according to Aristotle (1971), are required in order to achieve happiness and freedom. Gregory Bateson (1972), on the other hand, differentiates between play and combat, drawing from the animal kingdom. Here, playing is opposed to serious activities required for life sustainment or defense from danger. In such dualisms Brian-Sutton Smith (1997) notices the rhetoric of frivolity, which carries in itself implicit work ethics, moving play into the domain of fun, non-seriousness and nonsense. Salen and Zimermann notice that in modern times this sort of rhetoric inverts the classic work ethic view of play, "against which all the other rhetoric exist as rhetoric of rebuttal" $(2003,305)$.

Games and play seem to be determined by their self-sufficiency and closely defined "magic circle", which is creating a temporary world within the ordinary one (Huizinga 1938/1992, 10). They remain on the opposite end of drudgery as long as they are non-serious (Huizinga 1938/1992, 10), unproductive (Caillois 1958/2001, 10), joyous (Scheuerl 1979, 69), and utterly absorbing (Huizinga $1938 / 1992,10)$, making the players lose themselves in the constellation of playful time and space. The 
magic element within the play experience points towards the very suspension of time, as if past and future did not exist. The time within play is defined and perceived as pastime, for the players need to be entirely captured by the game in order to play it. Pastime seems to synchronize permanence and simultaneity and enclose them within what the German pedagogue Hans Scheuerl $(1979,69)$ defines as presence and inner endlessness. The experience of being suspended in time and lost within the game has been also theorized from the perspectives of flow (Csikszentmihalyi 1990/2008) and immersion (Calleja 2011; Tekinbaş Salen and Zimmerman 2003).

Following the above logic, we may come to the conclusion that play itself makes no sense, but simply exists within its internal logic. Play creates sense and meaning and lays them upon its players. In contrast to work, it does not need any external references to be defined as such. Play carries its goal in itself. It is autotelic.

Unlike play, work is a productive activity, which leads to meaningful, often profit-oriented goals. In the $13^{\text {th }}$ century labor (from Latin laborem) designated a task to be performed. In the late $14^{\text {th }}$ century it was mostly associated with exertion of the body, possibly originating from the notion of "tottering under a burden" (from Latin labere) (Dictionary). The Middle Ages brought the meaning of work onto the path of till and hardship. Not without a reason, in the Anglo-Saxon linguistic tradition, the term also designates the suffering women experience while "in labor". Etymologically, labor seems to be connected with productivity, effort, and suffering, qualities through which it fundamentally differs from play. The laborious effort is undertaken for the value of work lies outside of it and is encapsulated in its produced commodities. Work is therefore exotelic.

In the digital age the differentiation between work and play gradually disappears and dissolves, and while doing so, it encodes the Protestant and capital-oriented logic of a productive human existence into play. As much as play enters the allegedly play-free domains of life, such as workspace, seemingly non-ludic practices pervade playgrounds. And it is precisely at the intersection between those ostensibly distinct practices of play and work, or playfulness and seriousness, where new spaces and forms come into being; where the lines between the imaginary, the symbolic and the real are blurred.

The digital machine itself unites those two seemingly mutually exclusive qualities. On the one hand, a computer is a digital calculator based on mathematical game theory (von Neumann 1928), performing work-related tasks; on the other, an entertainment center used in free time. From its early years the computer has found itself entangled at the intersection between work and leisure-related playful activities. It served as a computing and simulating aid at governmental departments, universities, research and cultural institutions. At the same time that very same assemblage of hardware and software was used to program the first games. In 1961 a group of researchers at the Massachusetts Institute of Technology developed Spacewar (1961), a space combat simulation, in order to demonstrate the capacities of the computing machines to the public in a compelling way. Today, in the developed parts of the world, the most popular digital machines (personal computers, smartphones, or tablets) are an indispensable part of work and leisure, permeating both spaces.

As Joost Raessens $(2010,6)$ notices when discussing the ludification of culture, play is not only characteristic of leisure, but also turns up in those domains that once were considered the opposite of play, such as education (e.g. educational games), politics (playful forms of campaigning, using gaming principles to involve party members in decision making processes) and even warfare (interfaces resembling computer games, the use of drones - unmanned remote-controlled planes - introducing war à la PlayStation). This flooding of life with game elements leads naturally to the presence of play (the activity of play) and playfulness (the attitude of play) in the domains previously reserved for or associated with serious endeavors, such as work. However, in order to understand this play-cantered dynamics we need to realize that the process of ludification of culture is not a one-way road. Our everyday life and work practices might resemble play. But equally so, our playgrounds seem to be turning into workspaces. As Alexander Galloway emphasizes "... labor itself is now play, just as play becomes more and more laborious" (2012). 
This mutual effect has been also noticed in the most recent collected volume The Gameful World (2015), devoted to ludification of various domains of life. Its editors emphasize that not only games and play move towards the center of our cultural, social, and economic existence, but also other realms of life impress their forms onto play (Deterding and Walz 2015, 7). Games migrate into new, also nonleisure, territories and while doing so, undergo changes. The latter phenomenon, in contrast to the ludification of culture is named the cultivation of ludus. Following the same logic, we have introduced the concept of labourization (Dippel and Fizek 2015) as a contrasting term to that of gamification (Deterding et al. 2011) ${ }^{4}$ or ludification (Raessens 2006, 2010, 2014; Mäyra 2015). It denotes the process of the permeation of play with work elements. However, the work-play relationship is neither fully embraced by the concepts of gamification and ludification, nor that of labourization.

In order to encompass the overlay of the work-play relationship, we are proposing the concept of interference, borrowing a term that originally was used in Physics to denote the superposition of waves. This concept allows us to describe the interactions between phenomena, and their transformative character. The elements, dynamics, and logics of play are moved into the workspace, and by doing so they modify it (ludification). At the same time the opposite process of influencing play with the elements of work is taking place (labourization). The proposed work/play interference model (fig. 2) delineates the relation between supposedly non-productive playful activities and productive work-related behaviors. It illustrates the dissolving distinction between the two qualities, and surpasses a strictly dualistic mode of thinking. By doing so it has the chance to characterize the complexities and impurities of social praxis more accurately.

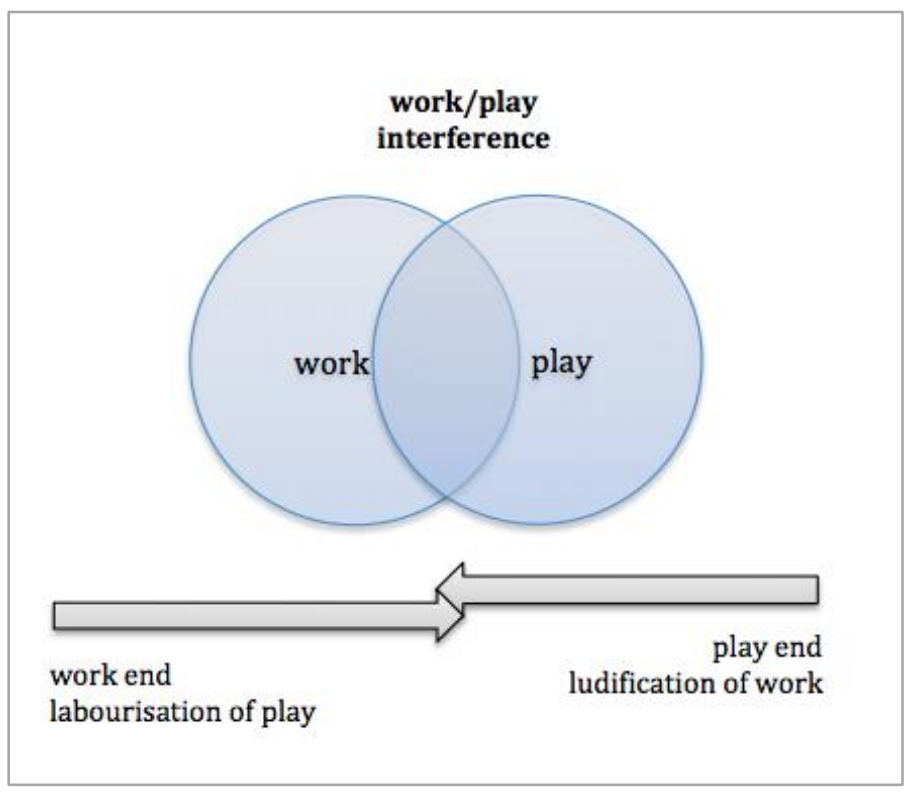

Fig. 2 A diagrammatic visualization of the work and play continuum as work/play interference model.

Within the model of interference, work and play appear as polar modalities of human interaction. On the one hand, they may be described separately from each other. On the other, they influence each other reciprocally, and within the moment of hermeneutical analysis and empirical research may be observed in their overlaying condition (Dippel and Fizek 2015). When the seriousness of work turns into jolly playfulness, and when the playful frivolousness transforms back into serious work, one may observe the processes of work-play interference.

Online citizen science ludic laboratories are considered a priori pleasurable and leisure-oriented game spaces, they are especially successful in enabling "productive activities of connected human minds" (Terranova 2013, 42). The players make a voluntary decision to contribute to the digital economy.

\footnotetext{
${ }^{4}$ In its purely mechanistic understanding, gamification is described as the implementation of game design elements into originally non-game contexts with the aim of influencing human behavior.
} 
They are not motivated by the monetary compensation for hours of their immaterial work. Similarly to other participants of the digital economy (fan fiction writers, "modders", amateur web designers), they are acting out of the desire for cultural production. They are willingly contributing to the development of knowledge, being motivated and rewarded on numerous levels, for instance by the internal elements of the game's system itself - from points, levels, and badges, to status in the gaming community. EteRNA operates according to reinforcement strategies based on leveling up. The player folds the ever more complex patterns and is awaiting the results, while watching the animated test-tube simulating a chemical process. Such animations introduce a dramatic climax that may be resolved in the epiphany of a successful protein assemblage, and allow the players to experience little eureka moments within the game. Those scientific discoveries reinforced by the numerical system give the player a luring promise of completion. The motivation to perform playful citizen science is also enticed by external factors, such as the will to contribute to something greater than the game itself. The scientists recognize the citizen community's efforts, and test the protein fold-up results of the best players in their laboratories or acknowledge the players in the academic papers. This immediate leverage of a playful and pleasant activity with socially productive outcome, the element of competition in a large collaborative environment, and the feeling of belonging to a research community with a common goal, form the basis of citizen science games as the examples of work/play interference.

What remains fascinating in this work/play constellation is the relationship between the human, the machine, and the data. The human agents contributing to research in the big data collaborative online games for science are of two kinds - the scientist and the citizen science player. Their roles played out in the human-machine assemblage are distinct and contrasting although both of them rely upon the ludic simulation. A team of scientists in the laboratory is analyzing the already sieved data in search for the significant pieces. The deluge of data is beforehand classified, labeled, and identified by players, each sitting in front of their own computer, which together with thousands of other calculating machines form a networked production line. In this sense, citizen science games resemble virtual assembly lines where big data is mined in an iterative factory-like system. The machine, on the other hand, stores the big data, runs the game, calculates the results delivered by thousands of players, communicates between the players and the scientific team, and networks the whole community. Most importantly, it learns from the human behavior.

\section{Into the Age of Interferences and Postludification}

[W] hat becomes of games when the sharp line dividing their ideal rules from the diffuse and insidious laws of daily life is blurred?

(Caillois 1958/2001, 43)

Playing is a fundamental human activity (Tomasello 1999, 91). There is no culture known to ethnologists, historians, archaeologists or missionaries that would be devoid of games (Bally 1966, 61; Mäyra 2008, 37). The proclaimed century of play we are currently experiencing is not necessarily a novelty. Already in 1751 Daniel Bernoulli, a Swiss mathematician and physicist, wrote, "The century that we live in could be subsumed in the history books as: Free Spirits' Journal and the Century of Play“" (Bernoulli 1769, 387; quoted in Bauer 2006, 377 and Fuchs 2014, 131). ${ }^{5}$ Also, a few decades before the "Manifesto for a Ludic Century" was written (Zimermann 2013) and the ludification of culture entered the academic discourse (Raessens 2006, 2010, 2014), Huizinga and Brian Sutton-Smith analyzed play as a universal element permeating other domains of our lives - from language, myths, rituals (Huizinga 1938/1992, 13) to thought games, television, theatre, sexual intimacy, humor, celebrations and festivals, or gossip (Sutton-Smith 1997, 5).

The above examples point to a great diversity of play and the extension of play through other domains of life. They all, however, belong to the sphere of free time and entertainment. What has changed in the digital times is not as much the extent to which games permeate our everyday, but more

\footnotetext{
${ }^{5}$ In original: "Das gegenw.rtige Jahrhundert konnte man in den Geschichtsbüchern nicht besser, als unter dem Titel: Das Freygeister=Journal und Spielsaeculum nennen” (Bernoulli 1769, 387).
} 
importantly the interfering spaces of this permeation. As we have shown on the example of citizen science games, play has entered domains that previously had little to do with joyousness. In the case of games with purpose, play is as much a frivolous as a productive activity.

Also such free-time activities as fan fiction writing, modifying existing software and video games (developing "mods"), managing communities, or sharing content via social networks, are being monetized and respectively "laborized". Those leisure-related, playful and free activities are assigned monetary value and become products of the digital economy. After all, free labor is not only based upon idealism of creativity abundance and community building, but also on the capitalistic understanding of knowledge as added value. More importantly, free digital labor is performed voluntarily and is perceived as a pleasant activity - "[i]t does not feel, look, or smell like labor at all" (Scholz 2013, 2). And this aspect is particularly interesting as it further blurs the distinction between playfulness and work.

The complexities of work and play and their mutual interdependencies and superpositions are also the subject of a recent anthropological study, describing and analyzing the collaborative work practices amongst videogame developers and the significance of play in workspace respectively (O'Donnell 2014). Building upon T.L. (2006, 72-73), he refers to this playful labor or laborious play dimension as work/play interplay, and observes the overlaps on numerous levels, from the collaborative team work and the playful work conduct to the very arrangement of space in companies, where employees can climb, play volleyball, or lift weights.

As idyllic as the above vision of labor may seem, O'Donnell emphasizes that the new modes of work practice, based on the blurred distinction between what is work and what is play, may as well dissolve into „destructive work practices“ $(2015,31)$. For as much as such playful work scheme encourages people to think creatively, it also pushes them to invest more time into work, giving the videogame producers and publishers the possibility to extend the developer's work week even to up to 80 hours.

In such blurring of lines and the opening of the magic circle Caillois saw a contamination and corruption of play, which no longer remains within its fictitious boundaries. In his reasoning, the four elements of play (agon, alea, mimicry, ilinx) when devoid of playful convention transform into destructive activities, such as violence (the corruption of competition), superstition (the corruption of chance), alienation (the corruption of simulation), or alcoholism and drug addiction (the corruption of vertigo) (Caillois 1958/ 2001, 53-54).

The capital-oriented forms of laborized play or ludified work and destructive human drives described by Caillois are taking yet another form of skepticism with regards to citizen science games. Here, it is the interference between human and non-human players that may cause concerns. Currently, humans are excelling at solving puzzles and predicting patterns - skills, which form the basis of citizen science gameplay. However, the unparalleled power of the human brain in pattern recognition may soon be challenged by such algorithms as EteRNAbot, which is already on its way to synthesizing excellence. The learning digital machine is enticing fears born in the age of industrialization. The uncertainties of the past are mirrored in the digital age as journalists paint bleak visions of future games, in which humans are not competing against one another, not even against the machine, but in which we all serve as "intelligence-gathering slaves" in a playful factory simulated by a digital brain, playing with human pawns (Koerner 2012). We should realize, however, that such fearsome visions are still deeply rooted in the model of human-machine co-existence, where the main role of people is to supervise the machines, and the main role of the machines is to obediently perform upon the human command. In the digital times, when the machines and algorithms are ever more present and refined, we need to constantly re-negotiate and re-think our place in the playful and laborious everyday.

It is precisely such interferences, interplays, transgressions, crossed boundaries or blurred lines, which paint a large part of the most recent ludic landscape, and lead to the rise of the new modes of work/play. And these are possibly taking us into the age of postludification. The age in which we are not only saturating the everyday with playful forms of expression, but also immersing the frivolous play in productivity and labor. Or as Sicart also puts it, moving play into the realms of efficiency, 
seriousness and technical determinism (Sicart 2014, 5). At the outbreak of the postludic era proposed here, we need to decide whether we are embracing the transgressing playful technologies and phenomena as empowering, engaging, and participatory, or observing them with caution, restraint, or even suspicion in Caillois' spirit.

\section{References:}

Aristotle. 1971. Nikomachische Ethik. Leipzig: Reclam Verlag.

Bally, G. 1966. Vom Spielraum der Freiheit. Die Bedeutung des Spiels bei Tier und Mensch. Basel/Stuttgart: Schwabe.

Bateson, G. 1972. Steps to an Ecology of Mind. Chicago, IL: University of Chicago Press.

Bauer, G. 2006. Mozart, Kavalier und Spieler. In Mozart: Experiment Aufklarung, ed. By Herbert Lachmayer, 377-388. Hatje Cantz.

Bernoulli, D. 1756/1769. In Anonym, Die Kunst die Welt erlaubt mitzunehmen in den verschiedenen Arten der Spiele, so in Gesellschaften höhern Standes, besonders in der Kayserlich=Königlichen Residenz=Stadt Wien üblich sind, Bd. II, Nürnberg.

Blizzard Entertainment. 2004. World of Warcraft. PC.

Buckminster Fuller Institute. World Game. https://bfi.org/about-fuller/big-ideas/world-game.

Caillois, R. 1958, 2001. Man, Play and Games. Chicago: University of Illinois Press.

Calleja, G. 2011. In-Game: From Immersion to Incorporation. Cambridge, MA: The MIT Press.

Carnegie Mellon University, Stanford University. 2010. eteRNA. PC. http://www.eternagame.org/web.

CERN (Conseil Européen pour la Recherche Nucléaire). 2014. Higgs Boson Machine Learning Challenge. PC. https://higgsml.lal.in2p3.fr.

Csikszentmihalyi, M. 1990/2008. Flow: The Psychology of Optimal Experience. New York: Harper Perennial Modern Classics.

Deterding, S., Khaled, R., Nacke, E. L Dixon, D. 2011. Gamification: Toward a Definition. http://gamification-research.org/wp-content/uploads/2011/04/02-Deterding-Khaled-NackeDixon.pdf.

Deterding, S., Walz, S. P. eds. 2015. The Gameful World. Approaches, Issues, Applications. Cambridge, MA: The MIT Press.

Dictionary.com. 1995/2016. Based on American Heritage and Harper Collins. http://dictionary.reference.com.

Dippel, A., Fizek. S. 2015. Playful Laboratories. The significance of games for knowledge production in the digital age. (paper presented at: Digital Games Research Association, DiGRA: Diversity of Play, Centre for Digital Cultures, Lüneburg, Germany, May 14-17, 2015). http://digra2015.org.

Elster, J. 1999. Karl Marx: A Reader. Cambridge, New York, NY: Cambridge University Press.

Fuchs, M. 2014. Predigital Precursors of Gamification. In Rethinking Gamification, eds. Mathias Fuchs, Sonia Fizek, Niklas Schrape, Paolo Ruffino. Lüneburg: meson press.

Galloway, A. 2013. The Interface Effect. Malden, MA: Polity Press.

Holy Bible. 2011. Genesis 3: 19. In Holy Bible: King James Version. New York, NY: HyperCollins Publishers.

Huizinga, J. 1938/1992. Homo Ludens: A study of the play-element in culture. Boston, MA: Beacon Press.

ITVS Interactive. 2007. World Without Oil. Multimedia. http://worldwithoutoil.org.

King. 2012. Candy Crush. Web browser. Apple iOS. Android.

Koerner I. B. 2012. New videogame lets amateur researchers mess with RNA. The Wired. July 5. http://www.wired.com/2012/07/ff_rnagame.

Ludwig-Maximilian University of Munich. 2010. ARTigo. Web browser. https://www.artigo.org.

Ludwig-Maximilian University of Munich. 2012. Metropolitalia. Web browser. http://www.metropolitalia.org.

Marx, K. 1858/1973. Grundrisse. Introduction to the Critique of Political Economy. Transl. from German with a Foreword by Martin Nicolaus. New York, NY: Random House.

Marx, K. 1887/2015. The Fetishism of Commodities and the Secret Thereof. In Capital. A Critique of Political Economy. https://www.marxists.org/archive/marx/works/1867-c1/ch01.htm\#S2.

Massachussets Institute of Technology. 1961. Spacewar. PDP-1.

Mäyra, F. 2008. An Introduction to Game Studies. Games in Culture. London: Sage Publications. 
Mäyra, F. 2015. Playful Culture: Are We Undergoing a Ludic Turn? (keynote presented at: Clash of Realities, Cologne, Germany, Nov. 4, 2015). http://www.clashofrealities.com.

McGonigal, J. 2010. Gaming can make a better world (TED video presentation). https://www.ted.com/talks/jane_mcgonigal_gaming_can_make_a_better_world. Scholz, T., ed. 2013. In Digital Labour: the Internet as Playground and Factory. New York, NY: Routledge, 2.

McGonigal, J. 2011. Reality is Broken. Why games make us better and how they can change the world. New York, NY: Penguin Press.

O'Donnell, C. 2014. The Developer's Dilemma. The Secret World of Video Game Creators. Cambridge, MA: MIT Press.

PopCap Games. 2011. Bejeweled. PC. Webbrowser. Apple iOS. Android.

Raessens, J. 2006. Playful Identities, or the Ludification of Culture. Games and Culture. A Journal of Interactive Media 1 (1): 52-57.

Raessens, J. 2010. Homo Ludens 2.0. The Ludic Turn in Media Theory. Utrecht: Utrecht University Press.

Raessens, J. 2014. The Ludification of Culture. In Rethinking Gamification, eds. Mathias Fuchs, Sonia Fizek, Niklas Schrape, Paolo Ruffino. Lüneburg: meson press.

Scheuerl, H. 1979. Das Spiel. Untersuchungen über sein Wesen, seine pädagogischen Möglichkeiten und Grenzen. Weinheim/Basel: Beltz.

Scholz, T. 2013. Introduction: Why Does Digital Labor Matter Now? In Digital Labour: the Internet as Playground and Factory, ed. by Trebor Scholz. New York, NY: Routledge.

Sicart, M. 2014. Play Matters. Cambridge, MA: The MIT Press.

Statista. Number of World of Warcraft subscribers from 1st quarter 2005 to 3rd quarter 2015 (in millions). http://www.statista.com/statistics/276601/number-of-world-of-warcraft-subscribers-byquarter.

Sutton-Smith, B. 1997. The Ambiguity of Play. Cambridge, MA: Harvard University Press.

Taylor, T.L. 2006. Play between Worlds: Exploring Online Gaming Culture. Cambridge, MA: MIT Press.

Tekinbaş Salen, K., Zimmerman, E. 2003. Rules of Play. Game Design Fundamentals. Cambridge, MA: The MIT Press.

Terranova, T. 2013. Free Labor. In Digital Labour: the Internet as Playground and Factory, ed. Trebor Scholz. New York, NY: Routledge.

The Citizen Science Alliance. 2007. Galaxy Zoo. PC. http://www.galaxyzoo.org.

The Galaxy Zoo. 2013. Galaxy Challenge. https://www.kaggle.com/c/galaxy-zoo-the-galaxychallenge.

Tomasello, M. 1999. A Natural History of Human Cognition. Cambridge, MA: Harvard University Press.

University of Washington. 2008. FoldIT. PC. https://fold.it/portal.

Von Neumann, J. 1928. Zur Theorie der Gesellschaftsspiele. Mathematische Annalen 100 (1): 295320.

Wired Differently. 2012. Eye Wire. PC. https://eyewire.org/signup.

World Bank Institute. 2011. Evoke. Multimedia. http://www.urgentevoke.com. 